\title{
Genetic Diversity, Heritability and Correlation of Quantitative Traits Sweet Corn (Zea Mays L. Var. Saccharata Sthurt) Ms-Unsika Inbred Lines
}

\author{
Muhammad Syafii ${ }^{1}$, Fatkhu Rokhman ${ }^{2}$, Asep Harpenas ${ }^{3}$ \\ \{muhammad.syafii@staff.unsika.ac.id ${ }^{1}$,fatkhu_rokhman@panahmerah.id ${ }^{2}$, \\ harpenas@panahmerah.i. $\left.\bar{d}^{3}\right\}$
}

\begin{abstract}
Plant Breeding and Biotechnology Department, Faculty of Agriculture, University of Singaperbangsa Karawang-Indonesia (UNSIKA), http://unsika.ac.id ${ }^{1}$

PT. East West Seed Indonesia, Desa Campaka Kab. Purwakarta, Indonesia , http://panahmerah.id ${ }^{2}$
\end{abstract}

\begin{abstract}
Sweet corn is an important commodity in Indonesia as the second main carbohydrate source after rice. Along with the growth in population, the demand for corn is increasing. Breeding programs to obtain high-yielding varieties are needed to compensate for the lack of higher demand for corn. Selection is the main activity in plant breeding programs that aims to increase the frequency of characters desired to be used as elders in crosses. Selection based on quantitative characters is difficult because many genes are controlled, but the success of selection can be improved by considering genetic parameters such as means, varians, heritability and genetic correlation. The aim of the study was to select sweet corn lines based on genetic parameters that are directly related to the yield. The study was conducted in July 2018 - December 2018 in the Experimental Station of PT. East West Seed Indonesia, Campaka Village, Purwakarta Regency. The genetic material used was 14 MS-Unsika sweet corn lines and 3 commercial sweet corn. The results showed that there was a high diversity of sweet corn lines tested. Characteristics of plant height, ear height, ear diamater, ear length, cob weight per plant, weight of 100 seeds, number of rows per ear had heritability and a high correlation with yield of tons per hectare. The MS 08 line is the best line as a candidate for hybrid parents.
\end{abstract}

Keywords: correlation, genetic variability, heritability, MS-Unsika lines, sweet corn

\section{Introduction}

Corn (Zea mays L.) is an important commodity in Indonesia, considering that this commodity has a multipurpose function, both for food, feed, and industrial raw materials [1]; [2]; [3]. One of the corn cultivars that plays a major role in the economy in Indonesia is sweet corn. Sweet corn is obtained from ordinary corn which has recessive mutations spontaneously, this mutation can control the conversion of sugar into starch in the endosperm. This sweet corn has a wrinkled and transparent seed character, with a high sugar content and low starch content in the endosperm [4]. Sweet corn can double sugar levels (around 12-14 \%) and 8-10 times more soluble in water than normal young corn. Sweet corn contains a relatively high sugar content, sweetness is caused by three main genes, namely the sugary (su) gene, sugary enhancer (se), and shrunken (sh2). Sweet corn cultivars which contain the su gene, produce a high amount of 
sugar, but changes sugar into starch quickly after harvest if the cob is not in a cold temperature [5]. Sweet corn cultivars containing se genes produce higher amounts of sugar than cultivars containing the su gene. Cultivars containing se genes will also convert sugar into starch such as normal sweet corn, but the process takes longer after harvest because the sugar content is higher. Sweet corn cultivars containing sh2 gene, do not directly convert sugar to starch and therefore after harvest the sweetness lasts for a very long time. At present the productivity of sweet corn is still relatively low so it needs to be improved.

Strategies for increasing sweet corn production can be carried out with plant breeding programs to obtain new varieties. The formation of new superior varieties, disease resistance and high production is the right strategy to solve the productivity problems of sweet corn. Crossing is one step to increase genetic variability and obtain a new genotype. The new genotypes that have been obtained are selected again to obtain better and superior genotypes. Corn breeders use morphological and agronomic markers in selection and crossing, although the expression of morphological and agronomic markers is sometimes influenced by environmental conditions and sometimes also influenced by epistatic and pleiotropic interactions [6], [7]. The success of plant breeding programs, especially sweet corn, is highly dependent on the diversity of germplasm. Germplasm diversity can be measured based on the phenomenon of performance of morphological, agronomic and molecular markers. Selection can be done if germplasm has a high level of genotype and phenotype diversity [8], [9], [10].

Analysis of genetic diversity between prospective hybrid parents, can be seen with molecular markers and agromorphological markers to obtain high heterosis, it is no longer necessary to cross all existing material, but only choose inbreds that have far genetic distances and have high yield potential. Quantitative genetic theory has explained the correlation between pairs between parents and genetic distance with estimates of heterosis [11], [12], [13]. Heterosis is a quadratic function of the difference between the frequency of alleles in the parent, namely genetic differences and also the dominant effects of alleles that control characters. Then, heritability is the relationship between genotype variants and variant phenotypes [14]. This relationship illustrates how far the visible phenotype is a reflection of the genotype. Basically, selection of segregated populations can be done through the value of phenotypic character quantities in the population. In selecting a plant character, attention is given to genetic diversity, heritability, and genetic progress. Selection will be more effective if there is extensive genetic diversity in the population. Heritability is very important in determining the selection method and in which generation the desired character should be selected. Genetic progress illustrates the extent of the effectiveness of the breeding process. Selection will be more effective if the value of high genetic progress is supported by the value of genetic diversity and high heritability. Thus the three genetic parameters greatly determine the success of the breeding program [15], [16].

The aim of the study was to obtain information on genetic diversity between sweet corn inbred lines based on quantitative traits and to find out genetic distances based on agromorphological markers of yield components to be tested further.

\section{Material and Methods}

\subsection{Genetic Materials and Experimental Site}


The fourteen inbred lines and three commercial hybrid of sweet corn were evaluated for yield performance and quantitative traits at the Experimental Station of PT. East West Seed Indonesia, Campaka Village, Purwakarta Regency, Indonesia and the experiments were laid out in a randomized complete block design in three replicates during July untill December, 2018.

\subsection{Data Collecting}

Quantitative traits parameters data were collected from yield component as follows: ear diameter without husk $(\mathrm{EDWOH})$, ear diameter with husk $(\mathrm{EDWH})$, ear length $(\mathrm{EL})$, ear diameter (ED), number row per ear (NRE), number grain per row (NGR), number grain per ear (NGE), sugar content (SC), ear weight per plot (EWP), ear weight per plant with husk (EWPWH), and ear weight per plant witout husk (EWPWoH).

\subsection{Data analysis}

Analysis of variance (ANOVA) was carried out to establish the level of significance among genotypes using the STAR 2.0.1 Software from IRRI@2013. The mean values were compared using the least significant difference (LSD) procedure.

\subsubsection{Analysis of Phenotypic Variance and Genotypic Variance}

The variability of each quantitative trait was estimated by simple statistical measures including the mean, phenotypic and genotypic variances and coefficient of variation. The phenotypic and genotypic variation and coefficient of variation were calculated following the formula suggested by [14] and [6]. Phenotypic and genotypic variances were computed from the respective mean squares as suggested [14].

\subsubsection{Genetic Distance}

The level of genetic similarity (GS = genetic similarity) is estimated using the Jaccard coefficient [17]. Genetic similarity was analyzed based on Unweighted Pair Group Method using Arithmetic Averages (UPGMA) using NTSYS-pc Software version 2.1.0. Analysis of genetic distance matrices is obtained from the results of genetic similarity analysis [18], with a formula: $\mathrm{S}=1$ - GS, where $\mathrm{S}=$ genetic distance, $\mathrm{GS}=$ genetic similarity. The cophenetic correlation coefficient (r) is also calculated followed by the Mantel test [19] to see the goodness of fit from the results of cluster analysis.

\subsection{Phenotypic Variance ( $\delta 2 p)$} Table 1:

The formula for the components of variance and heritability used are as follows ([14]) at 
Table 1. Analysis of variance agronomical and morphological traits of sweet corn genotypes

\begin{tabular}{ccccc}
\hline Source & DF & Mean Square & F Value & $\operatorname{Pr}(>F)$ \\
\hline Rep (r) & r-1 & $M_{\mathrm{r}}$ & & \\
Genotipe $(\mathrm{g})$ & $\mathrm{g}-1$ & $\mathrm{MS}_{\mathrm{g}}$ & $\sigma_{\mathrm{e}}^{2}+\mathrm{r} \cdot \sigma_{\mathrm{g}}^{2}$ & \\
G a l a t & $(\mathrm{g}-1)(\mathrm{r}-$ & $\mathrm{MS}_{\mathrm{e}}$ & $\sigma^{2} \mathrm{e}$ & \\
( e ) & 1) & & & \\
T o t a l & g.r-1 & & & \\
\hline
\end{tabular}

$$
\begin{aligned}
& \sigma 2 \mathrm{~g}=\frac{\mathrm{MSg}-\mathrm{MSe}}{\mathrm{r}} \\
& \sigma 2 \mathrm{p}=\sigma 2 \mathrm{p}+\sigma 2 \mathrm{e} \\
& \mathrm{GCV}=\left(\frac{\sqrt{V g}}{X}\right) \cdot 100 \% \\
& \mathrm{PCV}=\left(\frac{\sqrt{V p}}{x}\right) \cdot 100 \%
\end{aligned}
$$

Broad-sense heritability (h2 bs) was calculated as suggested by [6]:

$$
\mathrm{h} 2 \mathrm{bs}=\frac{\sigma 2 g}{\sigma 2 p}
$$

Where :

$\sigma 2 \mathrm{~g}=$ genotype variance

$\sigma 2 \mathrm{p}=$ Phenotype variance

$\mathrm{MSg}=$ mean square of genotype

$\mathrm{r}=$ replication

$\mathrm{X}=$ grand mean for the trait considered

$\mathrm{h} 2 \mathrm{bs}=$ heritability in the broad sense

$\mathrm{GCV}=$ genotypic coefficient of variation;

$\mathrm{PCV}=$ phenotypic coefficient of variation

The broad-sense heritability value according to Stanfield (1983) is: $0.50<\mathrm{h} 2<1.00$ : high; 0.20 $<$ h2 <0.50: medium; h2 <0.20: low.

Phenotypic and genotypic correlations were estimated as:

$$
\mathrm{r}_{G(x y)}=\frac{\operatorname{Cov}_{G(x y)}}{\sqrt{\left(\sigma_{G x}^{2}\right)\left(\sigma_{G y}^{2}\right)}}
$$

\section{Results and Discussion}

The results of research on genetic diversity, heritability and the genetic distance of the sweet corn inbred lines of the Unsika collection based on quantitative characters can be shown below. The results of the analysis of variance shown in Table 1 show that all the characters observed were significant. The parameters observed were: ear diameter without husk (EDWoH), ear diameter with husk (EDWH), ear length (EL), ear diameter (ED), number row per ear (NRE), 
number grain per row (NGR), number grain per ear (NGE), sugar content (SC), ear weight per plot (EWP), ear weight per plant with husk (EWPWH), and ear weight per plant witout husk (EWPWoH).

Table 2. Analysis of variance for agronomical traits of Sweet corn inbred lines MS- Unsika.

\begin{tabular}{lrrrrl}
\hline \multicolumn{1}{c}{ Agronomical Traits } & DF & Mean Square & F Value & Pr $(>$ F $)$ & Remarks \\
\hline EDWH & 16 & 0.4154 & 7.23 & $0.000^{*}$ & Significance \\
EDWoH & 16 & 0.5604 & 15.00 & $0.000^{*}$ & Significance \\
EL & 16 & 21.1281 & 7.05 & $0.000^{*}$ & Significance \\
ED & 16 & 0.1288 & 3.23 & $0.0023^{*}$ & Significance \\
NRE & 16 & 11.863 & 2.77 & $0.007^{*}$ & significance \\
NGR & 16 & 241.9063 & 3.11 & $0.003^{*}$ & significance \\
NGE & 16 & 79507.7298 & 3.58 & $0.001^{*}$ & Significance \\
SC & 16 & 7.7889 & 5.08 & $0.000^{*}$ & Significance \\
EWP & 16 & 53.6749 & 15.61 & $0.000^{*}$ & Significance \\
EWPWH & 16 & 0.0218 & 16.86 & $0.000^{*}$ & Significance \\
EWPWoH & 16 & 0.0173 & 13.8 & $0.000^{*}$ & significance \\
\hline Not EDWH
\end{tabular}

Notes: EDWH: ear diameter with husk; EDWoH: ear diameter without husk; EL: ear length; ED; ear diameter; NRE: number row per ear; NGR: number grain per row; NGE: number grain per ear; SC: sugar content; EWP: ear weight per plot; EWPWH: ear weight per plant with husk; EWPWoH: ear weight per plant without husk; ${ }^{*}:=\mathrm{p}<0.06$ :significance levels

Based on the results of observations and data analysis Table 3 shows that the estimation of genetic variability, the variation of phenotypes and heritability and the coefficient of variance in genotypes and the coefficient of phenotype variability in agronomic parameters shows that the coefficient of genotype diversity is low in ear length; ear diameter; row number per ear, ear weight per plant with husk and sugar content; while the coefficient of genotype diversity that is currently medium in characters ear diameter with husk; ear diameter without husk, number grain per row; number grain per ear; ear weight per plant without husk and ear weight per plot. The results of this analysis indicate that breeding will succeed if the germplasm possessed has high genetic diversity [6], [20].

The heritability value of all quantitative characters observed was high, except for the number row per ear indicating low heritability; then, the ear diameter character, number grain per row and number grain per ear show medium heritability. This shows that quantitative characters that have high heritability values can be used as selection parameters for the selection of new superior hybrid elders in the sweet corn tested such as ear diameter with husk; ear diameter without husk; ear length; sugar content; ear weight per plot; ear weight per plant with husk; and ear weight per plant without husk. This is in accordance with the results of research conducted by [21], [22], [23], [24] 
Table 3. Means, estimates of genetic variance, phenotypic variance, broad sense heritability, genotypic coefficient of variation (GCV) and phenotypic coefficient of variation (PCV) for agronomical traits in sweet corn

\begin{tabular}{|c|c|c|c|c|c|c|c|c|}
\hline \multirow{2}{*}{$\begin{array}{l}\text { Agronomical } \\
\text { Traits }\end{array}$} & \multirow{2}{*}{ Mean } & \multirow{2}{*}{$\begin{array}{c}\text { Mean } \\
\text { Square- } \\
\text { Genotype }\end{array}$} & \multicolumn{2}{|c|}{ Varinces } & \multicolumn{2}{|c|}{ CV \% } & \multirow{2}{*}{$\begin{array}{c}\mathrm{h} 2 \mathrm{bs} \\
(\%)\end{array}$} & \multirow{2}{*}{$\begin{array}{l}\text { Heritability } \\
\text { Criteria }\end{array}$} \\
\hline & & & $\sigma 2 g$ & $\sigma 2 p$ & GCV & PCV & & \\
\hline EDWH & 1.1 & 0.4154 & 0.119333 & 0.176733 & 31.40423 & 38.21788 & 67.52169 & High \\
\hline EDWoH & 1.62 & 0.5604 & 0.174333 & 0.211733 & 25.77361 & 28.40401 & 82.33627 & High \\
\hline EL & 16.6 & 21.1281 & 6.044167 & 9.039767 & 14.81017 & 18.11217 & 66.86198 & High \\
\hline ED & 1.31 & 0.1288 & 0.029667 & 0.069467 & 13.1481 & 20.11949 & 42.70633 & Medium \\
\hline NRE & 13.12 & 11.863 & 2.525733 & 6.811533 & 12.11323 & 19.89247 & 37.08025 & Low \\
\hline NGR & 26.18 & 241.9063 & 54.74623 & 132.4138 & 28.2623 & 43.95386 & 41.3448 & Medium \\
\hline NGE & 364.07 & 79507.73 & 19096.45 & 41314.84 & 37.95696 & 55.83006 & 46.22176 & Medium \\
\hline $\mathrm{SC}$ & 12.94 & 7.7889 & 2.0854 & 3.6181 & 11.1599 & 14.69962 & 57.63799 & High \\
\hline EWP & 16.16 & 53.6749 & 16.74557 & 20.18377 & 25.32262 & 27.80096 & 82.96552 & High \\
\hline EWPWH & 0.3312 & 0.0218 & 0.006833 & 0.008133 & 24.95893 & 27.22977 & 84.01639 & High \\
\hline EWPWoH & 0.2182 & 0.0173 & 0.005333 & 0.006633 & 33.46914 & 37.32598 & 80.40201 & High \\
\hline
\end{tabular}

Notes: EDWH: ear diameter with husk; EDWoH: ear diameter without husk; EL: ear length; ED; ear diameter; NRE: number row per ear; NGR: number grain per row; NGE: number grain per ear; SC: sugar content; EWP: ear weight per plot; EWPWH: ear weight per plant with husk; EWPWoH: ear weight per plant without husk; $\sigma 2 \mathrm{~g}$ : genetic variance; $\sigma 2 \mathrm{p}$ : phenotypic variance; GCV: genotypic coefficient of variation; PCV: phenotypic coefficient of variation; h2 bs : broad-sense heritability.

In table 4 shows that the correlation coefficient between characters shows a high value between ear weight per plot with number grain per ear, ear length, ear diameter with husk; and ear diameter without husk; while ear diameter shows a high correlation between number row per ear; number grain per row; and number grain per ear. For sugar content there is no positive correlation with all other characters; ear weight per plant with husk. 
Table 4. Correlation coefficients among agronomical traits in sweet corn

\begin{tabular}{|c|c|c|c|c|c|c|c|c|c|c|c|}
\hline Traits & $\begin{array}{c}\text { EDWo } \\
\text { H }\end{array}$ & $\begin{array}{c}\text { EDW } \\
\text { H }\end{array}$ & EL & ED & $\begin{array}{c}\text { NR } \\
\text { E }\end{array}$ & $\begin{array}{c}\text { NG } \\
\text { R }\end{array}$ & $\begin{array}{c}\text { NG } \\
\text { E }\end{array}$ & SC & $\begin{array}{c}\mathbf{E W} \\
\mathbf{P}\end{array}$ & $\begin{array}{c}\text { EWP } \\
\text { WH }\end{array}$ & $\begin{array}{c}\text { EWPW } \\
\text { oH }\end{array}$ \\
\hline $\begin{array}{c}\text { EDWo } \\
\text { H }\end{array}$ & 1 & $0.89^{*}$ & $\begin{array}{c}0.63 \\
*\end{array}$ & 0.46 & 0.48 & $\begin{array}{c}0.53 \\
*\end{array}$ & $\begin{array}{c}0.57 \\
*\end{array}$ & $\begin{array}{c}0.1 \\
4\end{array}$ & $\begin{array}{c}0.95 \\
*\end{array}$ & $0.95^{*}$ & $0.91 *$ \\
\hline EDWH & & 1 & $\begin{array}{c}0.57 \\
*\end{array}$ & $\begin{array}{c}0.51 \\
*\end{array}$ & 0.53 & $\begin{array}{c}0.60 \\
*\end{array}$ & $\begin{array}{c}0.62 \\
*\end{array}$ & $\begin{array}{c}0.0 \\
7\end{array}$ & $\begin{array}{c}0.83 \\
*\end{array}$ & $0.83^{*}$ & $0.92 *$ \\
\hline EL & & & 1 & $\begin{array}{c}0.67 \\
*\end{array}$ & $\begin{array}{l}0.70 \\
*\end{array}$ & 0.58 & $\begin{array}{c}0.64 \\
*\end{array}$ & $\begin{array}{c}0.3 \\
0\end{array}$ & $\begin{array}{c}0.60 \\
*\end{array}$ & $0.60 *$ & $0.60^{*}$ \\
\hline ED & & & & 1 & $\begin{array}{c}0.73 \\
*\end{array}$ & $\begin{array}{c}0.60 \\
*\end{array}$ & $\begin{array}{c}0.65 \\
*\end{array}$ & $\begin{array}{c}0.2 \\
0\end{array}$ & 0.44 & 0.42 & 0.49 \\
\hline NRE & & & & & 1 & $\begin{array}{c}0.73 \\
*\end{array}$ & $\begin{array}{c}0.83 \\
*\end{array}$ & $\begin{array}{c}0.1 \\
3\end{array}$ & 0.47 & 0.47 & $0.55^{*}$ \\
\hline NGR & & & & & & 1 & $\begin{array}{c}0.98 \\
*\end{array}$ & $\begin{array}{c}0.1 \\
3\end{array}$ & 0.48 & 0.49 & $0.57 *$ \\
\hline NGE & & & & & & & 1 & $\begin{array}{c}0.1 \\
7\end{array}$ & $\begin{array}{c}0.53 \\
*\end{array}$ & $0.53 *$ & $0.61^{*}$ \\
\hline SC & & & & & & & & 1 & 0.16 & 0.15 & 0.08 \\
\hline EWP & & & & & & & & & 1 & $1.00 *$ & $0.91 *$ \\
\hline $\begin{array}{c}\text { EWPW } \\
\text { H }\end{array}$ & & & & & & & & & & 1 & $0.91 *$ \\
\hline $\begin{array}{c}\text { EWPW } \\
\text { oH }\end{array}$ & & & & & & & & & & & 1 \\
\hline
\end{tabular}

Notes: EDWH: ear diameter with husk; EDWoH: ear diameter without husk; EL: ear length; ED; ear diameter; NRE: number row per ear; NGR: number grain per row; NGE: number grain per ear; SC: sugar content; EWP: ear weight per plot; EWPWH: ear weight per plant with husk; EWPWoH: ear weight per plant without husk

Furthermore, based on the analysis of genetic diversity using NTSYS version 2.1.0 Software shows high genetic diversity with Euclidian distance 0.02-0.26 on quantitative characters (Figure.ure 1). In Figure.ure 1 the dendogram is divided into 2 clusters, namely cluster IA, IB and cluster II A, II B, subclass IIIA, III B. The distribution pattern among the 17 genotypes of the Sweet corn Unsika line based on qualitative characters is shown in Figure.ure 1. Spread pattern among 17 genotypes Sweet corn based on quantitative characters is shown in Figure.ure 1.

The graph is divided into 3 quadrants. Quadrant I consists of genotypes AB1 and AB2 with contributions of sugar content and ear weight per plot that influence the presence variation. Quadrant II contains genotypes AB2 and AB4, In quadrant III consists of genotype AB3 and AB5 with contributions character of ear diameter and ear number per row that affect variation. Figure.ure 2. Dendogram of clustering for genetic diversity based on agronomical traits in sweet corn inbred lines. 


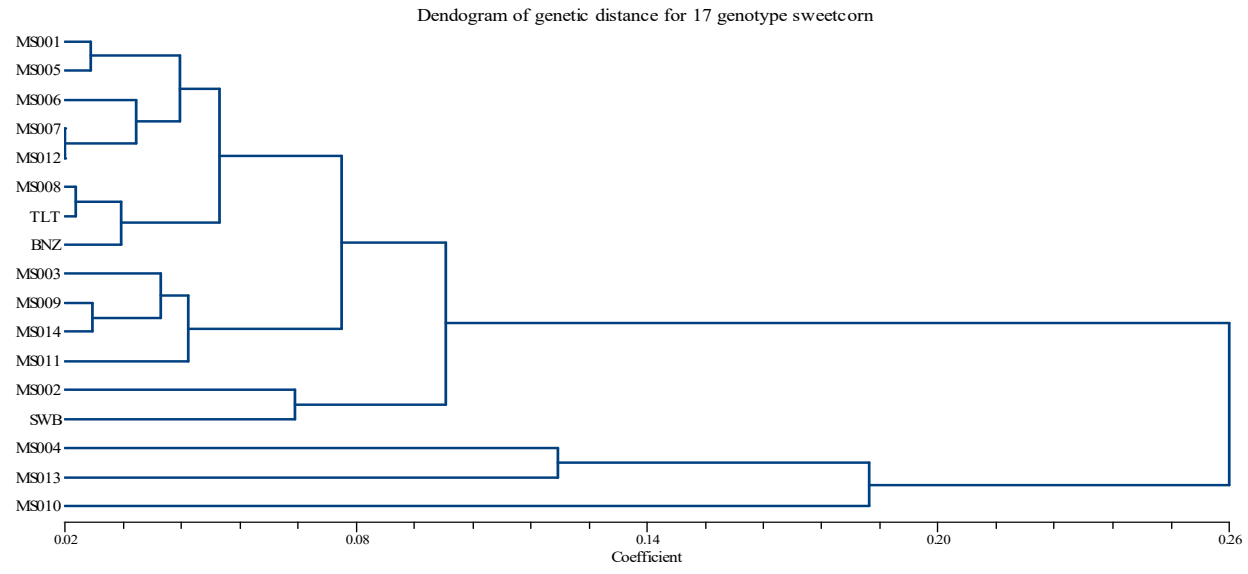

Figure. 1. Sweet corn Unsika line based on qualitative characters

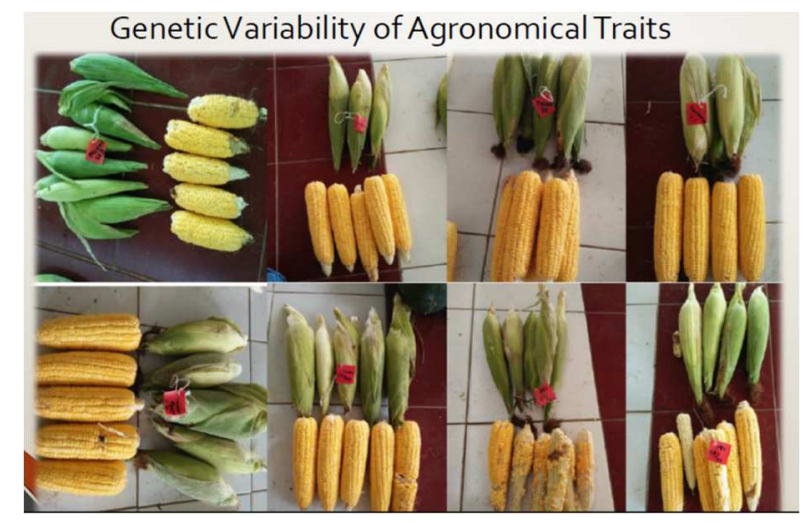

Figure. 2. Genetic diversity based on agronomical traits in sweet corn inbred lines

\section{Conclusion}

The results of this study concluded that the level of diversity of sweet corn tested based on quantitative characters was high, the genetic distance relationship between genotypes was also high so that it could be used for selection of prospective sweet corn parents; high heritability for all characters except sugar content; the best genotypes based on quantitative traits are MS 008 and MS 007; while the best hybrid is Bonanza F1.

Acknowledgement. We express our gratitude that this research was financed by PT. East West Seed Indonesia which has funded this research and the Faculty of Agriculture-University of Singaperbangsa Karawang which has given support so that the research will be successfully. 


\section{References}

[1] and D. R. M. Syafii, I. Cartika, "Multivariate analysis of genetic diversity among some maize genotypes under Maize-Albizia cropping system in Indonesia," Asian J. Crop Sci., vol. 7, no. 4, 2015.

[2] J. S. and D. Ruswandi, "Selection of Mutant Lines of Maize for Yield and Early Maturity Based on Line x Tester Analysis," pp. 18-20, 2014.

[3] and N. R. D. Ruswandi, B. Waluyo, A. Takdir Mak, E. Azizah, Y. Yuwariah, "Simple Sequence Repeats Analysis of New Indonesian Maize Inbred," Asian J. Crop Sci., vol. 9, no. 4, pp. 141$148,2017$.

[4] T. WF, "History, genetics, and breeding of supersweet (shrunken 2) sweet corn. Plant Breed Rev," Plant Breed Rev, vol. 14, pp. 189-236, 1997.

[5] N. Iriany, "Analisis Jarak Genetik Berdasarkan Marka SSRs dan Morfologi serta Analisis Daya Gabung untuk Pembentukan Hibrida Jagung Manis (Zea mays L. var. saccharata)," 2011.

[6] R. W., "Allard, Principles of Plant Breeding," New York/Chichester/London/Singapore/Sidney/Toronto John Wileys Sons, 1960.

[7] M. S. dan R. Y. Diah Ayu Ariani, "Pendugaan Parameter Genetik Dan Evaluasi Daya Hasil Enam Genotipe Cabai Half Diallel Pada Intensitas Cahaya Rendah," pp. 3-3, 2005.

[8] and R. N. I. P. Lestari, A. Risliawati, K. Nugroho, "( Evaluation of Genetic Diversity of Maize Inbred Lines Based on Ten Simple Sequence Repeat Markers ),” vol. 13, no. 2, pp. 83-90, 2017.

[9] and J.-M. R. D. Makumbi, J. F. Betrán, M. Bänziger, "Combining ability, heterosis and genetic diversity in tropical maize (Zea mays L.) under stress and non-stress conditions," Euphytica, vol. 180, no. 2, pp. 143-162, 2011.

[10] S. M. El-nahrawy, "Agro-Morphological and Genetic Parameters of some Cowpea Genotypes," 2018.

[11] N. H. et Al., "Comparison of methods for the estimation of best parent heterosis among lines developed from interspecific sunflower germplasm," Euphytica, vol. 214, no. 7, 2018.

[12] I. M. et Al., "Molecular, morphological and agronomic characterization of the sweet potato (Ipomoea batatas L.) germplasm collection from Mozambique: Genotype selection for drought prone regions," South African J. Bot., vol. 88, pp. 142-151, 2013.

[13] S. I. A. E. R. Apriyani, "Mutasi Induksi dengan Iradiasi Sinar Gamma secara Berulang pada Tunas In Vitro Celosia cristata L.," Semin. Nas. PERIPI 2017, pp. 472-482, 2017.

[14] B. D. and H. K. C. Singh, "Biometrical Methods in Quantitative Genetic Analysis," Ludhiana. New Delhi Kalyani Publ., 1979.

[15] V. R. A. M. R. and F. Jabeen, "NARROW SENSE HERITABILITY, CORRELATION AND PATH ANALYSIS IN MAIZE ( Zea mays L .),” vol. 48, no. 2, pp. 120-126, 2016.

[16] F. C. P. and K. J. Frey, "Genotypic Correlations, Dominance, and Heritability of Quantitative Characters in Oats," Crop Sci., vol. 6, no.3, pp. 259-262, 1966.

[17] F. J. Rohlf, "NTSYSpc Numerical Taxonomy and Multivariate Analysis System Version 2.0.," Appl. Biostat. Inc, New York, USA, 2001.

[18] M. Lee, "DNA markers for detecting genetic relationship among germplasm revealed for establishing heterotic groups.," Maize Train. Course, CIMMYT, Texcoco, Mex., p. 116, 1998.

[19] N. Mantel, "The detection of disease clustering and a generalized regression approach.," Cancer Res, vol. 27, pp. 209-220, 1967.

[20] K. S. and Suneetha, "Genetics and plant breeding," 2007.

[21] and K. S. R. L. Penelitian, P. Tungro, J. B. Lanrang, "Keragaman Genetik dan Heritabilitas Galur Padi Tahan Tungro," pp. 1-6, 2017.

[22] D. W. et Al., "Kendali Genetik Karakter Morfologi dan Agronomi pada Tiga Populasi Sorgum ( Sorghum bicolor ( L .) Moench ) Genetic Control of Morphology and Agronomic Characters in Three Sorghum ( Sorghum bicolor ( L .) Moench ) Populations,” vol. 45, no.3, pp. 285-291, 2017.

[23] and D. B. I. Scotti, L. Calvo-vialettes, C. Scotti-saintagne, M. Citterio, B. Degen, "Genetic 
variation for growth, morphological, and physiological traits in a wild population of the Neotropical shade - tolerant rainforest tree Sextonia rubra ( Mez ) van der Werff ( Lauraceae )," pp. 319-329, 2010.

[24] and G. N. A. R. Kumar, R. Venuprasad, "Genetic analysis of rainfed lowland rice drought tolerance under naturally-occurring stress in eastern India : Heritability and QTL effects," vol. 103, pp. 42-52 